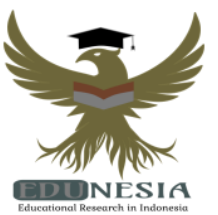

\title{
The Impact of Learning Loss due to Family Income Factors on Students' Achievement during the COVID-19 Pandemic
}

\author{
Falinda Oktariani ${ }^{1}$; Richa Fionasari2; Triana Ramdha ${ }^{3}$
}

\author{
1,2,3 Language Center, Riau University, Indonesia \\ ${ }^{1}$ Corresponding Email: falinda.oktariani@lecturer.unri.ac.id, Phone Number: 0852 xxxx xxxx
}

\section{Article History:}

Received: Okt 30, 2021

Revised: Nov 10, 2021

Accepted: Nov 15, 2021

Published: Nov 17, 2021

Keywords:

English Academic

Achievement,

Learning Loss,

Economics,

COVID-19 Pandemic

\section{Kata Kunci:}

Prestasi Akademik

Bahasa Inggris,

Penurunan kompetensi

belajar, Ekonomi,

Pandemi Covid-19

\section{How to cite:}

Oktariani, F., Fionasari, R., \& Ramdha, T. (2022). The Impact of Learning Loss due to Family Income Factors on Students' Achievement during the COVID-19 Pandemic. Edunesia: Jurnal Ilmiah Pendidikan, 3 (1): 12-20.

This is an open access article under the CC-BY-NC-ND license
Abstract: The purpose of this study is to examine online learning during the pandemic period from the learner's economic standpoint. Seeing how far family income influences student learning achievement from the perspective of mastering English. The data is derived from English academic achievement and a questionnaire focusing on students' economic situations, and it is analyzed using the SPSS version 23 application. After being determined to be homogeneous and normally distributed, the data was collected and analyzed to test the hypothesis using $\mathrm{R}$ Square and ANOVA techniques. The results show that family economic factors influence Riau University students' English proficiency as much as $69.7 \%$ in 2021 during the COVID-19 pandemic which may result in learning loss for the students.

Abstrak: Tujuan dari penelitian ini adalah untuk mengkaji pembelajaran online selama masa pandemi dari sudut pandang ekonomi pelajar. Melihat sejauh mana pendapatan keluarga mempengaruhi prestasi belajar siswa ditinjau dari penguasaan bahasa Inggris. Data berasal dari prestasi akademik bahasa Inggris dan kuesioner yang berfokus pada situasi ekonomi mahasiswa, dan dianalisis menggunakan aplikasi SPSS versi 23. Setelah ditentukan homogen dan berdistribusi normal, data dikumpulkan dan dianalisis untuk menguji hipotesis menggunakan teknik $\mathrm{R}$ Square dan ANOVA. Hasil penelitian menunjukkan bahwa faktor ekonomi keluarga mempengaruhi kemampuan bahasa Inggris mahasiswa Universitas Riau sebesar 69,7\% pada tahun 2021 pada masa pandemi COVID-19 yang dapat mengakibatkan hilangnya kemampuan belajar mahasiswa. 


\section{A. Introduction}

According to the most recent forecasts, Covid-19, the superstorm that wrecked the world economy last year, is expected to do so once more in 2021. In an article published on October 1, 2021, (Worldometers.info, 2021) stated that the daily number of positive Covid19 tests had risen to more than 480 thousand, bringing the total number of people infected by the virus to 239 million, with more than 4 million deaths as a result of the infection.

Like many other developing countries, Indonesia is highly vulnerable to the Covid19 outbreak, which has spread throughout the world (Barbier \& Burgess, 2020). A huge economic impact is expected, with the possibility of triggering a global recession as a result of the situation. According to the "The World Economic Outlook" (IMF, 2021), the global economy was growing at a negative $3.5 \%$ rate by 2020, which is worse than the rate of growth experienced during the global financial crisis of 2009 and the Asian monetary crisis of 1998 combined. Economic ramifications are also expected to be severe, according to predictions.

To halt the spread of the virus, countries worldwide implemented stringent measures such as complete or partial lockdowns, social distance rules, and curfews. To minimize the risk of people infecting one another with Covid-19, areas where humans contact frequently. Restriction of civic activities and enforced social separation - dubbed Pembatasan Social Berskala Besar (PSBB) in Indonesia - have wreaked havoc on the economy. Indonesia's unemployment rate surged to 6.26 percent in the first quarter of 2021, up from $4.94 \%$ a year earlier, owing to the economic slowdown brought about by the coronavirus outbreak. Unemployment increased by 1.82 million to 8.75 million. Meanwhile, employment decreased by 2.23 million to 131.06 million, with the highest declines in transportation and warehouse (-0.30 percent) and accommodation and food services $(+1.20 \%)(0.34 \%)$. In the meantime, the labor force participation rate fell to $68.08 \%$ in the first quarter, down from $69.21 \%$ a year before (Statistik, 2020).

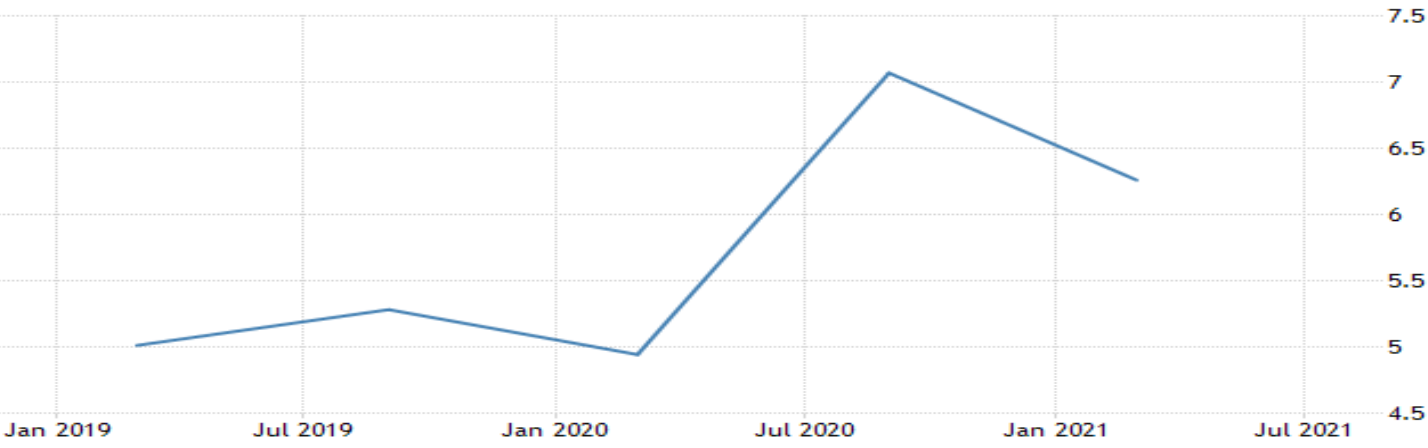

Figure 1. Unemployment rate

After winning the 2019 presidential election, President Joko 'Jokowi' Widodo firmly revealed his plan for 'Indonesia Emas 2045' (Golden Generation 2045), setting a goal for Indonesia to become one of the world's top five economies (Bappenas, 2019). However, the pandemic of COVID-19 has dramatically changed the country's growth trajectory - and possibly its long-term development route toward that aim. COVID-19 precipitated an ongoing economic crisis, resulting in job losses, decreased earnings, and an increase in the number of people living in poverty (Richard V. Reeves and Jonathan Rothwell, 2020). This preliminary evidence indicates that not only will the crisis have an immediate impact, with low-income workers suffering more than high-income workers, but that the current cohort 
of students' learning loss will have a long-term negative effect on their earnings, which will be felt over the course of their lives.

Globally, educational institutions closed their doors in 2020 due to the COVID-19 epidemic. The pandemic has wreaked havoc on educational systems worldwide, affecting $94 \%$ of pupils in more than 190 countries on all continents (Fiscal policy Agency-Ministry of Finance, 2020). To continue delivering education, educational institutions needed to react swiftly and transition to online learning. Under these worldwide conditions, educational institutions were unable to continue operations. As a result, alternate learning methods were adopted, such as the utilization of online learning platforms available to the entire academic community. This approach of instruction, which incorporates electronic equipment and information technology, was novel to the Indonesian educational system.

According to prior research (Rapanta et al., 2020), it is difficult to differentiate between classroom-based and online education because both are considered "heterogeneous." There are, however, advantages and disadvantages to this subject (Mukhtar et al., 2020); online learning is viewed as a supplement to traditional learning and a means of increasing student satisfaction and cost-effectiveness (Sadeghi et al., 2014), but it does not appear to be a substitute for the classroom environment, as students struggle to acquire the same amount of knowledge as they would in a traditional environment (Zhang et al., 2007).

A well-structured and coordinated lesson plan, technological abilities, instructional materials, early preparation, and experience teaching online are all necessary components of a successful online course. Additionally, studies demonstrate that kids who are isolated experience a range of challenges, including a lack of desire and access to appropriate learning environments (Bao, 2020). If students are having difficulty, faculty staff can ascertain whether they require assistance by seeing and reacting to them and attempting to take control of the situation, which is not always achievable with online learning.

There is a direct correlation between a student's upbringing and future academic success. For the duration of the epidemic, researchers looked at the relationship between students' academic achievement and their family's income or poverty condition. Considering that the coronavirus pandemic and its effects are still being felt in Indonesia, it's critical to look at how economic and social changes are affecting schooling.

The study's purpose is to find out how much income and poverty affect university students' academic performance. This study will look at how income and unemployment have changed in Indonesia after establishing correlations between economic variables and academic performance. Accordingly, the study's original hypothesis was that wealth and educational attainment have high correlations, as did poverty and education.

As a result, the following research concerns will be addressed in this study: To begin, how substantial are the statistically significant disparities in academic achievement across pupils from various socioeconomic backgrounds? Second, is there a correlation between academic achievement and family wealth among students, and if so, what is the strength of the correlation? Finally, is there a correlation between poverty and academic performance among pupils, and if so, how strong is that correlation?.

\section{B. Method}

The study employs a simple random sampling technique, with a sample size of 139 Riau University students. Students completed a questionnaire in the form of a google form that was distributed via the Whatsapp application in this study. Prior to distribution, the 
questionnaire underwent validity and reliability tests to ascertain its accuracy and precision, which were then analysed using the SPSS version 23 application. The hypothesis test was conducted after the normality and homogeneity tests were passed. The following hypotheses are being considered: English academic achievement among students of different family incomes; The effect of the family income on student learning loss during the pandemic; and Learning loss affect the categories of academic achievement of the students during pandemic.

\section{Result and Discussion Normality and Homogeneity Test}

The normality distribution test, as defined by Adam Kolkiewicz, Gregory Rice, n.d. (2021), is a test that determines whether or not the data has a normal distribution. There are several methods for determining the data's normality. They are classified into two types: graphical and statistical. The Kolmogorov-Smirnov Test is a popular statistical technique. The One-Sample Kolmogorov-Smirnov test with SPSS was used to determine the data's normality. The following is the analysis:

Table 1. One-Sample Kolmogorov-Smirnov Test

\begin{tabular}{llll}
\hline & & $\mathrm{X}$ & $\mathrm{Y}$ \\
\hline $\mathrm{N}$ & & 139 & 139 \\
\hline Normal Parameters, & Mean & 11.417 & 411.611 \\
& & 3 & 5 \\
\cline { 2 - 4 } & Std. & 2.3953 & 45.5045 \\
& Deviation & 4 & 0 \\
\hline Most Extreme & Absolute & .113 & .110 \\
\cline { 2 - 4 } Differences & Positive & .111 & .104 \\
\cline { 2 - 4 } & Negative & -.113 & -.110 \\
\hline Kolmogorov-Smirnov Z & 1.327 & 1.296 \\
\hline Asymp. Sig. (2-tailed) & & .059 & .070 \\
\hline
\end{tabular}

a. Test distribution is Normal.

b. Calculated from data.

According to the table 1, the Asymp. Value. Sig. (2-tailed) on both variables is greater than 0.05 . It denotes that the data for both variables are normally distributed. Furthermore, it is frequently necessary to determine whether a set of data is homogeneous before applying any statistical technique to it. Data from a single population are used to generate homogeneous data (Gorbunova \& Lemeshko, 2012). In other words, for the entire time period of the sample, all external processes that could potentially affect the data must remain constant. The researcher used SPSS's Homogeneity of Variances function to determine the data's homogeneity, as shown below.

Table 2. Test of Homogeneity of Variances

\begin{tabular}{|r|r|r|r}
\hline $\begin{array}{c}\text { Levene } \\
\text { Statistic }\end{array}$ & df1 & df2 & \multicolumn{1}{c}{ Sig. } \\
\hline 1.696 & 1 & 137 & .195 \\
\hline
\end{tabular}


Table 2 indicates that the variance of the group is identical ( $\mathrm{P}$-value $=0.195)$, indicating that the data from this study are homogeneous, as the significance level (P-value) is greater than 0.05 .

\section{English academic achievement among students of different family incomes}

The coefficient of determination ( $\mathrm{R}$ Square), also known as $\mathrm{R} 2$, is defined as the independent variable's $(X)$ contribution to the dependent variable's (Y) (AKOSSOU, 2013). In other words, the R2 value can be used to predict and determine the extent to which family economic factors influence the English proficiency of Riau University students in 2021 during the COVID-19 pandemic.

Table 3. Model Summary, The Extent of Family Economic Factors Influence the Students' English Academic Achievement

\begin{tabular}{c|c|c|c|c|}
\hline Model & $\mathrm{R}$ & $\begin{array}{c}\mathrm{R} \\
\text { Square }\end{array}$ & $\begin{array}{c}\text { Adjusted R } \\
\text { Square }\end{array}$ & Std. Error of the Estimate \\
\hline 1 & $\begin{array}{c}.773 \\
\mathrm{a}\end{array}$ & .697 & .694 & 28.97676 \\
\hline
\end{tabular}

a. Predictors: (Constant), X

The R Square value obtained is 0.697 , as shown in Table 3. Based on this value, it can be concluded that the $X$ variable has a 69.7 percent effect on the $Y$ variable. This figure indicates that the variable family economic factor has a 69.7 percent effect on the variable learning loss of students. The remainder (100 percent -69.7 percent $=30.3$ percent) is influenced by variables outside of this regression equation or variables that are not investigated.

\section{The effect of the family income on student learning loss during the pandemic}

To determine the significance of the effect of family income on student learning loss during the pandemic, the ANOVA test was used. Because it requires a normal distribution on the dependent variable per treatment or a normal distribution on the residuals, ANOVA is one of several types of parametric tests. This normality requirement assumes that the sample was drawn at random and can represent the entire population, allowing the research findings to be generalized (Hahn, 2017).

Table 4. The ANOVA Test on the Effect of Family Income on Students' Learning Loss during Pandemic

\begin{tabular}{l|c|r|r|r|r}
\hline & $\begin{array}{c}\text { Sum of } \\
\text { Squares }\end{array}$ & df & $\begin{array}{c}\text { Mean } \\
\text { Square }\end{array}$ & F & Sig. \\
\hline $\begin{array}{l}\text { Between } \\
\text { Groups }\end{array}$ & 115689.917 & 1 & 115689.917 & 93.199 & .000 \\
\hline $\begin{array}{l}\text { Within } \\
\text { Groups }\end{array}$ & 170061.105 & 137 & 1241.322 & & \\
\hline Total & 285751.022 & 138 & & & \\
\hline
\end{tabular}


The P-value was calculated to be 0.000 at the 0.05 level of significance based on table 4 as a result, family income has a significant impact on student English academic achievement during pandemics.

\section{Learning loss affect the categories of academic achievement of the students during pandemic}

During the pandemic, descriptive analysis is used to determine how learning loss divides students' academic achievement levels. Descriptive analysis is a type of research data analysis that is used to test the generalizability of research findings based on a single sample. The activity of collecting, grouping, processing, analyzing, and presenting research data in a research sample group includes testing standard deviation, variance, data range, lowest value, highest value, total data, and research data average (Holcomb, 2016).

Table 5. Descriptive Analysis on How Learning Loss Affect the Typical Academic Achievement of Students during Pandemic

\begin{tabular}{|c|c|c|c|c|c|c|}
\hline & \multirow[t]{2}{*}{$\mathrm{N}$} & \multirow[t]{2}{*}{ Mean } & \multirow[t]{2}{*}{$\begin{array}{c}\text { Std. } \\
\text { Deviation }\end{array}$} & \multirow[t]{2}{*}{$\begin{array}{l}\text { Std. } \\
\text { Error }\end{array}$} & \multicolumn{2}{|c|}{$\begin{array}{l}\text { 95\% Confidence Interval } \\
\text { for Mean }\end{array}$} \\
\hline & & & & & $\begin{array}{l}\text { Lower } \\
\text { Bound }\end{array}$ & $\begin{array}{l}\text { Upper } \\
\text { Bound }\end{array}$ \\
\hline $\begin{array}{l}\text { Low } \\
\text { Impac } \\
t\end{array}$ & 58 & $\begin{array}{r}439.845 \\
1\end{array}$ & 36.33953 & 4.31271 & 431.2436 & 448.4465 \\
\hline $\begin{array}{l}\text { High } \\
\text { Impac } \\
t\end{array}$ & 81 & $\begin{array}{r}382.132 \\
4\end{array}$ & 34.03725 & 4.12762 & 373.8936 & 390.3711 \\
\hline Total & 139 & $\begin{array}{r}411.611 \\
5\end{array}$ & 45.50450 & 3.85964 & 403.9798 & 419.2432 \\
\hline
\end{tabular}

According to the table 5,58.3\% (81) of students have a low TOEFL score, with an average score of 382.13, as a result of their high exposure to learning loss. Meanwhile, with an average TOEFL score of $439.84,41.7 \%$ (58) of the remaining students were classified as having low exposure to learning loss. Unfortunately, neither of these groups achieved the minimum TOEFL passing score of 450 required by the University of Riau.

Participants' educational and personal experiences were exposed as a result of the COVID-19 crisis, according to the findings of this study, which indicated a variety of consequences for them. Given the fact that little research has been done to investigate the 'lived' experiences of college students during this pandemic, and that online learning may not be a one-time occurrence due to the lack of an active treatment, this study may provide some new insights and implications to consider as we move forward with our research.

In order to address the challenge domain in this study, students were asked to respond to Likert scale and an open-ended question (mention any challenges and difficulties you faced during online education). The lack of face-to-face interaction was found to be the most significant source of learning loss for the students. As a result, the lecturer's instructions to the students were widely misunderstood. According to the Education Trust (2020) poll, even when lecturers made themselves and their instructional materials available online, many students lacked the ability to access online materials from home. Nearly half 
of low-income families and $42 \%$ of average families did not have enough ICT devices at home (Lake, R., Dusseault, 2020). As Mukhtar points out, students' limited access to electronics and the internet is frequently emphasized in studies on online learning in developing nations, which is understandable given their circumstances (Mukhtar et al., 2020).

In addition, they faced difficulties due to insecurity and frequent power outages in their community, as well as their inability to afford internet service fees. They understood that having reliable energy in their village would make e-learning more accessible, allowing lecturers to continue their academic work and even conduct alternate classes to traditional classroom instruction. It is their belief that in the post-covid-19 period, in which uncertainties abound, the positive transformation will happen as a result of this. During online learning, low-income households faced severe technological challenges, including a lack of access to gadgets and a lack of consistent internet connectivity (Reich et al., 2020). Along with ability, online learning must consider students' financial circumstances, as well as the facilities and infrastructure that support online learning (Rusli et al., 2020).

Furthermore, even though the learning environment is virtual, the importance of physical space cannot be disregarded. A peaceful study environment with the same amenities as a classroom or library was a luxury that not everyone could make use of, and it was not available to everyone. According to the results of our poll, students who are taking online classes usually struggle to cope with their immediate environment.

Additional data corroborate the findings of this inquiry. According to Syauqi et al., (2020), students' perceptions on online learning varied. Only a minority of teachers believed that online learning enhanced student performance, and among other issues, learning resources were difficult to access. This finding is consistent with the study's findings, which indicate that lecturer-student relationships are not always optimal. On the other hand, students are not inherently opposed to the use of online education. When online learning is integrated and planned appropriately, the results are often favorable. According to the findings of a recent study, students respond positively to a variety of online learning platforms (Cakrawati, 2017); (Santi Maudiarti, 2018).

\section{Conclusion}

These preliminary projections reaffirm the fears of many educational leaders: lengthy absences from offline classes will almost surely have a detrimental effect on student success. This condition deteriorated further following the pandemic's economic impact.

Similarly, family economic, social, and cultural capital influences the adoption of everyday informal learning techniques that are more or less consistent with school reasoning, which rapidly amplifies disparities in learning chances and familiarity with what constitutes legitimate information. University lockout has not had the same effect on all children, and significant material and human resources will be required to guarantee that the most vulnerable children catch up. To restore students' socio-emotional and cognitive abilities, an educational emergency plan with social and educational objectives will be required. Individual and collective consequences of inaction are simply too great, unjust, and uneven. States and countries bear responsibilities for ensuring the right to education in these trying times.

This study, we believe, is part of a growing corpus of significant work that builds on past research to enable school leaders, policymakers, and academics to make critical evidence-based decisions following the implementation of COVID-19. 


\section{References}

Adam Kolkiewicz, Gregory Rice, Y. X. (n.d.). Katalog: 3101028. Projection Pursuit Based Tests of Normality with Functional Data, Journal of Statistical Planning and Inference, 211. https://doi.org/doi.org/10.1016/j.jspi.2020.07.001.

AKOSSOU, A. Y. J. (2013). Impact of data structure on the estimators R-square and adjusted R-square in linear regression. International Journal of Mathematics and Computation, January 2013. http:/ / www.ceser.in/ceserp/index.php/ijmc/article/view/2579

Bao, W. (2020). COVID-19 and online teaching in higher education: A case study of Peking University. March, 113-115. https://doi.org/10.1002/hbe2.191

Bappenas. (2019). Berdaulat, Maju, Adil dan Makmur. https://www.bappenas.go.id/files/Visi Indonesia 2045/Ringkasan Eksekutif Visi Indonesia 2045_Final.pdf

Barbier, E. B., \& Burgess, J. C. (2020). Sustainability and development after COVID-19. World Development, 135, 105082. https:// doi.org/10.1016/j.worlddev.2020.105082

Cakrawati, L. M. (2017). Students' Perceptions on the Use of Online Learning Platforms in EFL Classroom. English Language Teaching and Technology Journal (ELT-Tech Journal, $1(1), 22-30$.

Education Trust. (2020). Covid-19: Impact on Education Equity, Resources, \& Responses. https://edtrust.org/covid-19-impact-on-education-equity-resources-responding/

Fiscal policy Agency-Ministry of Finance. (2020). Policy Brief: The Impact of COVID-19 on Child Poverty and Mobility in Indonesia. Unicef, 1-16.

Gorbunova, A. A., \& Lemeshko, B. Y. (2012). Application of parametric homogeneity of variances tests under violation of classical assumption. Applied Methods of Statistical Analysis, https://www.researchgate.net/publication/236162433_Application_of_Parametric _Homogeneity_of_Variances_Tests_under_Violation_of_Classical_Assumption

Hahn, M. M. A.-M. M. A.-T. M. A.-P. G. A.-H. S. A.-U. (2017). Global envelope tests for spatial processes. Journal of the Royal Statistical Society, v. 79(2), 381-404-2017 v.79 no.2. https://doi.org/10.1111/rssb.12172

Holcomb, Z. (2016). Fundamentals of Descriptive Statistics. Fundamentals of Descriptive Statistics. https://doi.org/10.4324/9781315266510

IMF. (2021). World Economic. May.

Lake, R., Dusseault, B. (2020). Remote classes are in session for more school districts, but attendance plans are still absent. Center for Reinventing Public Education. https://www.crpe.org/thelens/remote-classes-are-session-more-school-districtsattendance-plans-are-still-absent

Mukhtar, K., Javed, K., Arooj, M., \& Sethi, A. (2020). Advantages, limitations and recommendations for online learning during covid-19 pandemic era. Pakistan Journal of Medical Sciences, 36(COVID19-S4), S27-S31. https://doi.org/10.12669/pjms.36.COVID19-S4.2785

Rapanta, C., Botturi, L., Goodyear, P., Guàrdia, L., \& Koole, M. (2020). Online University Teaching During and After the Covid-19 Crisis: Refocusing Teacher Presence and Learning Activity. Postdigital Science and Education, 2(3), 923-945. https://doi.org/10.1007/s42438-020-00155-y

Reich, J., Buttimer, C., Fang, A., Hillaire, G., Hirsch, K., Larke, L., Littenberg-Tobias, J., Moussapour, R. M., Napier, A., Thompson, M., \& Slama, R. (2020). Remote Learning 
Guidance From State Education Agencies During the COVID-19 Pandemic: A First Look. https://doi.org/10.35542/osf.io/437e2

Richard V. Reeves and Jonathan Rothwell. (2020). Class and COVID: How the Less Affluent face Double Risks. https://www.brookings.edu/blog/up-front/2020/03/27/classand-covid-how-the-less-affluent-face-double-risks/

Rusli, R., Rahman, A., \& Abdullah, H. (2020). Student perception data on online learning using heutagogy approach in the Faculty of Mathematics and Natural Sciences of Universitas Negeri Makassar, Indonesia. Data in Brief, 29, 105152. https://doi.org/10.1016/j.dib.2020.105152

Sadeghi, R., Sedaghat, M. M., \& Sha Ahmadi, F. (2014). Comparison of the effect of lecture and blended teaching methods on students' learning and satisfaction. Journal of Advances in Medical Education \& Professionalism, 2(4), 146-150. http://www.ncbi.nlm.nih.gov/pubmed/25512938\%0Ahttp://www.pubmedcentr al.nih.gov/ articlerender.fcgi?artid=PMC4235559

Santi Maudiarti. (2018). Penerapan E-Learning Di Perguruan Tinggi. PERSPEKTIF Ilmu Pendidikan, 32(1), 53-68.

Statistik, B. P. (2020). STATISTIK Pertumbuhan Ekonomi. 64, 1-12.

Syauqi, K., Munadi, S., \& Triyono, M. B. (2020). Students' perceptions toward vocational education on online learning during the COVID-19 pandemic. International Journal of Evaluation and Research in Education, 9(4), 881-886. https://doi.org/10.11591/ijere.v9i4.20766

Worldometers.info. (2021). COVID-19 CORONAVIRUS PANDEMIC. Dover, Delaware, U.S.A. https:/ / www.worldometers.info/coronavirus/

Zhang, W., Spurlock-Johnson, J. I., \& Gao, X. (2007). Can E-learning replace the traditional classroom? A case study at a private high school. Proceedings of the Information Systems Education Conference, ISECON, 24, 1-7. 